\section{Australian Journal of \\ Crop Science}

AJCS

ISSN:1835-2707

\title{
Potential use of ash from sugarcane bagasse to produce passion fruit seedlings
}

\author{
Henrique Guimarães de Favare ${ }^{1}$, Sandra da Costa Preisigke*2 ${ }^{2}$, Leonarda Grillo Neves ${ }^{3}$, Kelly Lana Araújo ${ }^{3}$, \\ Milson Evaldo Serafim, José Renato Maurício da Rocha ${ }^{4}$
}

\author{
${ }^{1}$ University Federal Mato Grosso, department of Agronomy, Brazil \\ ${ }^{2}$ University State Mato Grosso, department of Agronomy, Bazil \\ ${ }^{3}$ University State Mato Grosso, department of Agronomy, Bazil \\ ${ }^{4}$ Federal Institute of Education, Science and Technology of Mato Grosso, Brazil
}

\section{*Corresponding author: sandrapreisigke@hotmail.com}

\section{Abstract}

\begin{abstract}
The production of good quality passion fruit seedlings depends on substrates with adequate physical and chemical characteristics. Therefore, this experiment was conducted to evaluate the effect of doses of ash from burning of sugarcane bagasse on improvement of traits of the substrate "gully soil". The experiment was set up in a greenhouse and arranged in randomized block design, in a $2 \times 7 \times 2$ factorial scheme. The following factors and their respective levels were studied: (i) soil structure,- aggregating between 4 and $10 \mathrm{~mm}$ and $<2 \mathrm{~mm}$; (ii) ash doses - 0; 1.5; 3; 6; 12; 24; and $48 \mathrm{t}$ ha-1; (iii) families of passion fruit - F29 and F48. The use of ash combined to the soil with structure $<2 \mathrm{~mm}$ significantly increased the production of shoot fresh mass and shoot dry mass for both families studied. The density of the substrate obtained by the mixture of ash and gully soil (soil) decreased as ash doses increased, regardless of the size of the aggregates and the family studied.
\end{abstract}

Keywords: organic matter; Passiflora edulis; soil structure; substrate; water availability.

Abbreviations: CAV_ water consumption per pot; DS_ soil density, F29 e F48_Half-sib families passion fruit; $\mathrm{g} \mathrm{cm}^{-3} \mathrm{gram}_{\text {per }}$ cubic centimeter; Kg_kilogram; MFPA_shoot fresh mass; $\mathrm{mL} \_$Milliliter; MSPA_shoot dry mass; mm_millimeter; RLe_eutrophic Red Latosol; t ha- ${ }^{1}{ }_{-}$ton per hectare; UNEMAT / UFV / UENF_ State University of Mato Grosso / Federal University of Viçosa/ University Norte Fluminense Darcy Ribeiro

\section{Introduction}

Brazil is the world's largest producer of passion fruit, with a production of 703,489 tons (IBGE, 2018). However, production and productivity have been hampered by various phytosanitary problems and inappropriate management techniques. Among the proper management techniques, the production of healthy and vigorous seedlings is fundamental for the successful formation and renovation of orchards. Besides, the selection of the substrate is an essential factor for seedling quality (Oza et al., 2018). The reaction of different varieties of passion fruit, also, is essential for success in the orchard, since it is known that there is genetic variability within the species $P$. edulis (Reis et al., 2012; Silva et al., 2014; Jesus et al., 2014), which may contribute to the unevenness of the seedlings.

The search for economically viable alternatives and the development of environmental awareness have directed research related to the use of agricultural and agroindustrial residues in the formulation of substrates for the production of seedlings (Kratz et al., 2013). In the cultivation of passion fruit, goat manure (Sá et al., 2014), vermicompost and charcoal rice husk (Santos et al., 2014) and sewage sludge (Freitas et al., 2015), were used as substrate alternatives for seedling production.
Plants need substrates with chemical, physical and microbiological characteristics that allow for adequate root system growth in its early stage of development (Freitas et al., 2015). Thus, the use of many mineral and organic products may be important in this process, without increasing expenses to the nursery (Oliveira et al., 2013). This would strengthen the role of passion fruit cultivation in family agriculture, which generally counts on low investment capacity. Therefore, sugarcane bagasse ash has great use potential. The application of vegetal ash in agricultural plantations presents itself as an opportunity of restitution of part of the nutrients removed by the crops.

Ash has been successfully used in vineyard fertilization (Piva et al., 2013) and in the cultivation of Pinus sylvestris (Saarsalmi et al., 2006), and it was verified that the applications of vegetal ashes in doses of $0 ; 1 ; 2.5$ and $5 \mathrm{t} \mathrm{ha}^{-1}$ significantly increased the volume of wood produced, and provided higher values of $\mathrm{pH}$ and extractable $\mathrm{Ca}$ in the soil.. Ashes from the burning of sugarcane bagasse have aroused interest due to their potential as fertilizer and soil conditioner and possible use in substrate formulation. Their positive characteristics include high retention capacity and water permeability, content of macronutrients and micronutrients, ability to improve soil physical attributes and 
increase the soil pH (Cunha et al., 2015). There are no reports of the use of sugarcane bagasse ash in the production of passion fruit seedlings.

The production of passion fruit seedlings is one of the most important stages in the crop cycle, since when they are grown in a substrate that meets their essential needs (Costa and Camargo, 2009), they can withstand the adverse conditions of the planting site (Duarte et al., 2010). Therefore, the objective of this study was to evaluate the effect of ash doses from the sugarcane bagasse burning as conditioner of soil substrate from the B horizon, with and without its preserved structure, for the production of passion fruit seedlings.

\section{Results and discussion}

The summary of the analysis of variance (Table 1) demonstrated that the family study factor was significant for MFPA, MSPA, DS and CAV. The aggregate factor was significant for MFPA, MSPA, DS, and CAV. The ash factor was significant for MFPA and DS. Other sources of significant variation were the double interactions Family:Aggregate and Family:Ash for DS; Family (ash^2) for MSPA, DS, and CAV; Aggregate:Ash for MFPA and DS, while the triple interactions were not significant.

The tables with the estimates of the model parameters (Tables 2 and 3 ) are presented below. The factors aggregate and ash significantly affect the variables MFPA and MSPA. For 10 to $4 \mathrm{~mm}$ aggregates, each unit of ash increases the MFPA in $6.14 \mathrm{~g}$ in relation to the aggregate $<2 \mathrm{~mm}$. In the 10 to $4 \mathrm{~mm}$ reference aggregate, there was an increase of $0.34 \mathrm{~g}$ in MFPA per unit of ash. For aggregates $<2 \mathrm{~mm}$, the MSPA gain was $0.07 \mathrm{~g}$ for each unit of ash. These results evidence the positive effect of ash combined with underground soil with preserved structure (10 to $4 \mathrm{~mm}$ ).

All factors significantly affected the variables DS and CAV (Tables 4 and 5), including the interactions. For the family F29 conducted in 10 to $4 \mathrm{~mm}$ aggregates + zero ash dose, the intercept for DS is $1.278 \mathrm{~g} \mathrm{~cm}-3$, and DS is reduced at the rate of $0.0087 \mathrm{~g} \mathrm{~cm}-3$ for each unit of ash added. On the other hand, for the family F48, the intercept was $1.286 \mathrm{~g} \mathrm{~cm}$ 3 , ie $0.0158 \mathrm{~g} \mathrm{~cm}-3$ higher than the family F29, which reveals a likely effect of the genetic differences between families. However, this genetic aspect cannot be detailed in this study. For CAV, the results are similar to those of DS, with reduction of $122.6 \mathrm{~mL}$ per unit of ash added to the substrate of the family F29 (Table 5).

The addition of ash at both soil structure levels $(<2 \mathrm{~mm}$ and 10 to $4 \mathrm{~mm}$ ) resulted in distinct MFPA responses (Figure 1). There was a significant MFPA increase for the ash doses for the treatments with aggregates $<2 \mathrm{~mm}$ in relation to the treatments with 10 to $4 \mathrm{~mm}$ aggregates. The same significant effect was observed for MSPA (Figure 1B). The combination of aggregates $<2 \mathrm{~mm}$ and ash provided better conditions for the development of passion fruit seedlings. Visually, when the pots were disassembled for root collection, a high proportion of voids was observed in the substrate with a 10 to $4 \mathrm{~mm}$ structure, due to the lack of contact between the large aggregates. Good seedling growth requires an adequate balance between aeration porosity and water retention, besides sufficient stiffness to support the plants (Landis et al., 1990), which was verified by combining ash and aggregate $<2 \mathrm{~mm}$. The substrate acquired features similar to those provided by commercial substrates (Mendonça et al., 2003). The combination of fine particles (ash), medium ( $<2 \mathrm{~mm}$ ) and coarse (10 to 4) particles should be the proper mixture, since only fine particles and coarse particles did not achieve the desired result.

The positive effect of the addition of organic residues to the soil to prepare substrates for seedling production was described in the results found by Pio et al. (2005). Ash, combined with gully soil $<2 \mathrm{~mm}$ can be associated to the improved physical and chemical attributes resulting from the use of organic waste. This is in agreement with the findings of Pio et al. (2005), who used coconut fiber mixed with underground soil. Ferreira et al. (2002) also observed that the substrates dosed with the addition of organic materials presented better results for root system dry mass weight and pepper plant shoot. Ash is a residue with low density physical property besides its chemical property of containing nutrients for the nutrition of the seedlings (Bonfim-Silva, et al., 2017).

DS decreased as the ash doses increased for both levels of aggregates and families. The greatest reduction was found for the family F 48 (Figure 2A), which could not be detailed in this study, since genetic factors may have contributed to it.

The family F29 presented a minimum CAV point (Figure 2B), while no significant response was observed for F48 for the ash doses. Considering the relevance of decreasing the water consumption by seedlings, consequently increasing the time between irrigations, it is important to observe that the quadratic model for the two levels of structure in the family F29 indicates that the intermediate doses of ash increased water use efficiency. The combination of the ash doses with furrow soil generates a pore volume and peculiar arrangements for each dose, which can be proved by the density variation observed in Figure $2 \mathrm{~A}$. Zietemann and Roberto (2007) described the important role of the pore structure in the substrates to ensure the efficiency of water use for passion fruit seedlings.

In the growth curve for height, represented by the mathematical model (Figure 3), it was observed that the family factor did not significantly affect the final plant height. On the other hand, the ash factor affected the final height of plants of the family F29. It had a negative effect when combined with aggregates $<2 \mathrm{~mm}$, and positive effect for 4 to $10 \mathrm{~mm}$ aggregates. Arruda et al. (2007) claim that substrates with finer grain size lead to decreased proportion of macropores in the total porosity, which increases resistance to root penetration when dry, and less aeration when irrigated. This may negatively affect the development of the seedlings. Except for the family F29 combined with aggregates $<2 \mathrm{~mm}$, a flat figure can be observed at the beginning and at the end of the evaluation of the combinations, which indicates similarity in the final height between the treatments. However, the growth rate was higher for the 10 to $4 \mathrm{~mm}$ aggregates, in relation to the aggregates $<2 \mathrm{~mm}$. This indicates that the seedlings need less time to reach the desired height when they are grown with larger aggregates (Figure 3).

For final height gain, and the respective confidence intervals (Figure 4A), a significant difference was observed in both families in relation to ash ends ( 0 and $48 \mathrm{tha}^{-1}$ ) combined 
Table 1. Summary of the analysis of variance for shoot fresh mass (MFPA), shoot dry mass (MSPA), soil density (DS) and water consumption per pot (CAV).

\begin{tabular}{|c|c|c|c|c|c|}
\hline \multirow{2}{*}{ Sourceofvariance } & \multirow{2}{*}{$\mathrm{GL}$} & \multicolumn{4}{|c|}{ QM } \\
\hline & & MFPA & MSPA & DS & CAV \\
\hline Block & 2 & $1055.56^{* *}$ & $43.12^{* *}$ & $0.02^{* *}$ & $2352147.54^{\mathrm{ns}}$ \\
\hline Family & 1 & $88.60^{\mathrm{ns}}$ & $0.32^{\mathrm{ns}}$ & $0.05^{* *}$ & $12968148.67^{* *}$ \\
\hline Aggregate & 1 & $4122.36^{* *}$ & $80.26^{* *}$ & $0.02^{*}$ & $270606640.02^{* *}$ \\
\hline Ash & 1 & $1847.86^{* *}$ & $61.76^{\mathrm{ns}}$ & $0.82^{* *}$ & $550532.50^{\mathrm{ns}}$ \\
\hline $\mathrm{I}\left(\operatorname{ash}^{\wedge} 2\right)$ & 1 & $426.58^{\text {ns }}$ & $4.97^{\mathrm{ns}}$ & $0.09^{\text {ns }}$ & $2360352.49^{\mathrm{ns}}$ \\
\hline Interaction Family: Aggregate & 1 & $255.45^{\mathrm{ns}}$ & $1.24^{\mathrm{ns}}$ & $0.01^{* *}$ & $4240214.88^{\mathrm{ns}}$ \\
\hline Interaction Family:Ash & 1 & $431.40^{\mathrm{ns}}$ & $20.51^{\text {ns }}$ & $0.04^{* *}$ & $581539.07^{\mathrm{ns}}$ \\
\hline Family:I(ash ^2) & 1 & $558.40^{\mathrm{ns}}$ & $21.27^{* *}$ & $0.03^{* *}$ & $14011880.84^{* *}$ \\
\hline Interaction Aggregate: Ash & 1 & $837.02 *$ & $63.03^{\mathrm{ns}}$ & $0.03^{*}$ & $2821636.19^{\mathrm{ns}}$ \\
\hline Aggregate:I(ash^^2) & 1 & $27.72^{\mathrm{ns}}$ & $1.66^{\mathrm{ns}}$ & $0.02^{\text {ns }}$ & $13641.12^{\mathrm{ns}}$ \\
\hline Interaction Family: Aggregate: Ash & 1 & $253.60^{\text {ns }}$ & $11.24^{\mathrm{ns}}$ & $0.01^{\text {ns }}$ & $19103684.50 *$ \\
\hline Family: Aggregate:I(ash ^2) & 1 & $125.12^{\mathrm{ns}}$ & $7.39^{\text {ns }}$ & $0.00^{\text {ns }}$ & $291876.64^{\text {ns }}$ \\
\hline Residue & 154 & 160.53 & 8.19 & 0.00 & 1522638.23 \\
\hline
\end{tabular}

"and" significant at 1 and $5 \%$ probability, respectively. ${ }^{\text {ns }}$ non significant.QM: sum of average squares, GL: degrees of freedom.
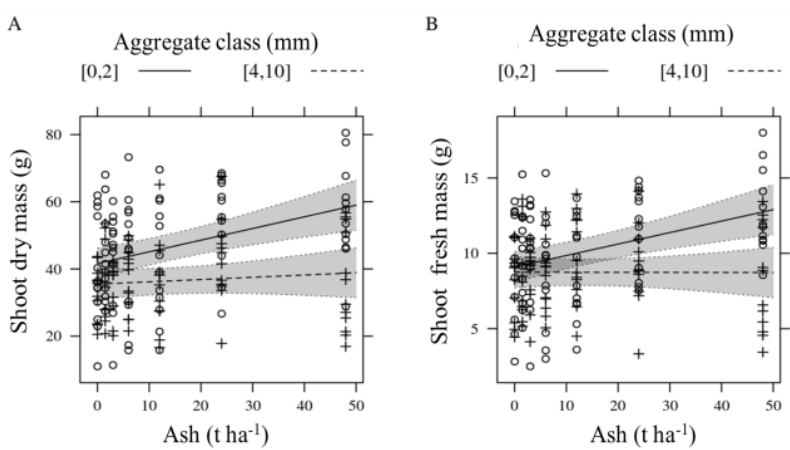

Fig 1. Values observed and predicted by the model for MFPA (A) and MSPA (B) according to the ash doses and classes of aggregates. The gray regions are the confidence intervals for the predicted values.

Table 2. Estimates of the parameters for the variable shoot fresh mass (MFPA).

\begin{tabular}{|c|c|c|c|c|}
\hline & Estimates & Standard Error & $\mathrm{t}$ & $\operatorname{Pr}(>|t|)$ \\
\hline (Intercept) & 41.6537 & 1.8384 & 22.66 & 0.0000 \\
\hline Block 1 & 3.7052 & 1.4057 & 2.64 & 0.0092 \\
\hline Block 2 & 1.0720 & 1.4057 & 0.76 & 0.4468 \\
\hline Aggregate $<2$ & -6.1442 & 2.5999 & -2.36 & 0.0193 \\
\hline Ash & 0.3464 & 0.0878 & 3.95 & 0.0001 \\
\hline Aggregate $<2$ : ash & -0.2787 & 0.1241 & -2.25 & 0.0261 \\
\hline
\end{tabular}
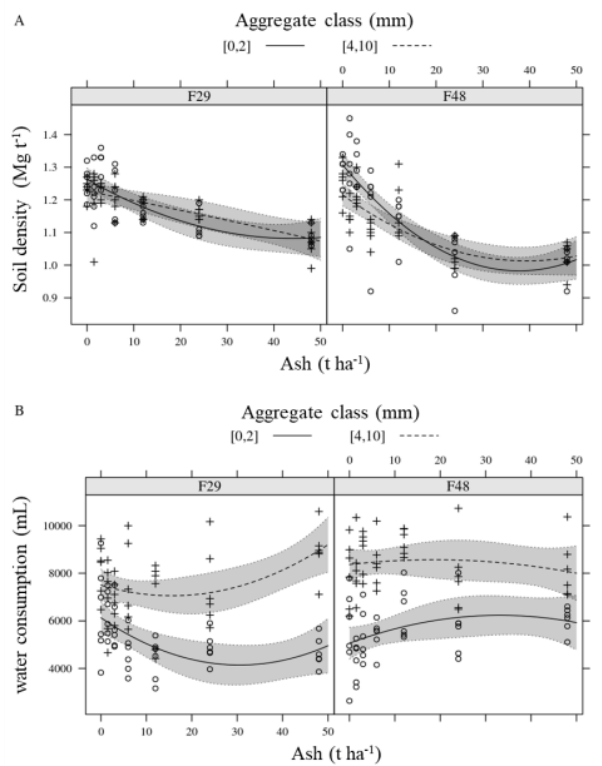

Fig 2. Values observed and predicted by the model for soil density (A) and water consumption per pot (B) according to the doses of ash, classes of the aggregate and family. The gray regions refer to the confidence intervals for the predicted values. 
Table 3. Estimates of the parameters for the variable shoot dry mass (MSPA).

\begin{tabular}{|c|c|c|c|c|}
\hline & Estimates & Standard error & $t$ & $\operatorname{Pr}(>|t|)$ \\
\hline (Intercept) & 9.0939 & 0.4106 & 22.15 & 0.0000 \\
\hline Block 1 & 0.6242 & 0.3140 & 1.99 & 0.485 \\
\hline Block 2 & 0.3792 & 0.3140 & 1.21 & 0.2290 \\
\hline Aggregate $<2$ & 0.3498 & 0.5807 & -0.60 & 0.5478 \\
\hline Ash & 0.0761 & 0.0196 & 3.88 & 0.0002 \\
\hline Aggregate $<2$ : ash & -0.0765 & 0.0277 & -2.76 & 0.0065 \\
\hline
\end{tabular}

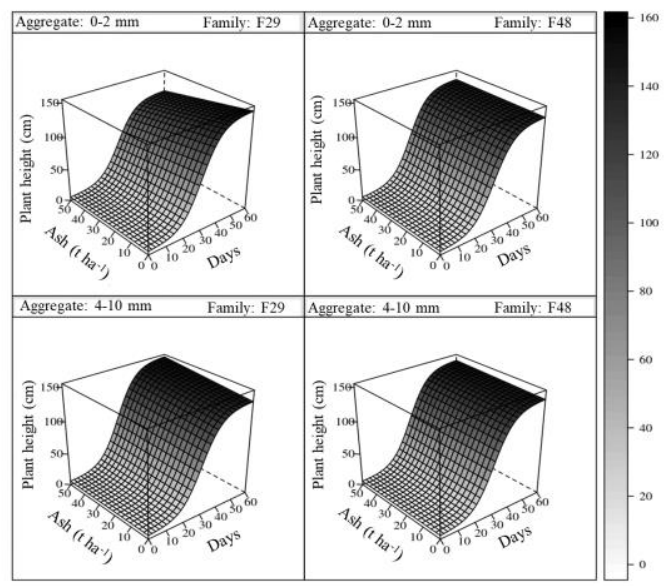

Fig 3. Plant height according to the days, ash content, family and class of aggregate.

Table 4. Estimates of the parameters for the variable soil density (DS).

\begin{tabular}{lllll}
\hline & & Estimates & $\mathrm{t}$ & $\operatorname{Pr}(>|\mathrm{t}|)$ \\
\cline { 2 - 5 } (Intercept) & 1.2776 & 0.0144 & 88.70 & 0.0000 \\
Block 1 & 0.0008 & 0.0072 & 0.12 & 0.9083 \\
Block 2 & -0.0202 & 0.0072 & -2.80 & 0.0057 \\
Family F48 & 0.0158 & 0.0166 & 0.95 & 0.3432 \\
Aggregate<2 & -0.0644 & 0.0166 & -3.87 & 0.0002 \\
Ash & 0.0087 & 0.0021 & -4.11 & 0.0001 \\
I(ash ^2) & 0.0001 & 0.0000 & 2.19 & 0.0303 \\
Family F48: ash & -0.0082 & 0.0024 & -3.37 & 0.0010 \\
Aggregate<2: ash & 0.0062 & 0.0024 & 2.54 & 0.0120 \\
Family F48:I(ash ^2) & 0.0001 & 0.0000 & 2.71 & 0.0074 \\
Aggregate<2:I(ash ^2) & -0.0001 & 0.0000 & -1.97 & 0.0502 \\
\hline
\end{tabular}

A
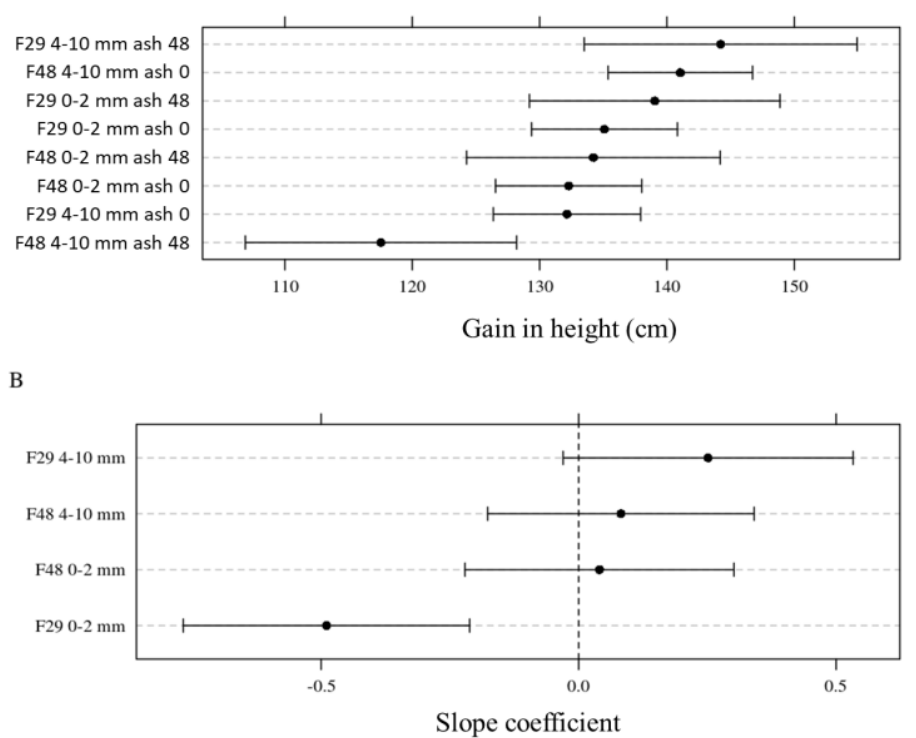

Fig 4. Gain in height of passion fruit seedlings according to family, aggregate class and extreme doses of ash (A) and interval estimation for the parameter of height gain rate per unit of ash (B). 
Table 5. Estimates of the parameters for the variable water consumption per pot (CAV).

\begin{tabular}{lllll}
\hline & Estimates & Standard error & $\mathrm{t}$ & $\operatorname{Pr}(>|\mathrm{t}|)$ \\
\cline { 2 - 5 } (Intercept) & 6099.970 & 279.503 & 21.82 & 0.000 \\
Block 1 & -113.191 & 133.856 & -0.85 & 0.399 \\
Block 2 & -123.387 & 133.857 & -0.92 & 0.358 \\
Family F48 & -989.458 & 395.277 & -2.50 & 0.013 \\
Aggregate<2 & 1433.598 & 350.134 & 4.09 & 0.001 \\
Ash & -122.687 & 32.903 & -3.73 & 0.003 \\
I(ash ^2) & 1.975 & 0.649 & 2.04 & 0.003 \\
Family F48: Aggregate<2 & 1772.459 & 495.164 & 3.58 & 0.001 \\
Family F48: Ash & 181.956 & 46.531 & 3.91 & 0.001 \\
Aggregate<2: Ash & 58.294 & 16.718 & 3.49 & 0.001 \\
Family F48:I(ash ^2) & -2.801 & 0.918 & -3.05 & 0.003 \\
Family F48: Aggregate < 2:(ash ^2) & -84.221 & 23.640 & -3.56 & 0.001 \\
\hline
\end{tabular}

with 10 to $4 \mathrm{~mm}$ aggregates, which was not observed for aggregates $<2 \mathrm{~mm}$, regardless of the family studied. For the gain in height per unit of ash (Figure 4B), there was a positive effect for the family F29 combined with 10 to $4 \mathrm{~mm}$ aggregates, compared to the same family in aggregates $<2$ $\mathrm{mm}$, whose slope coefficient was negative. In contrast, the rate of gain in height per unit of ash applied does not differ from zero in the two sizes of aggregates for the family F48. The increase of fine particles given by the dose of $48 \mathrm{t}$ ha- 1 in the substrate formed by aggregates of 10 to $4 \mathrm{~mm}$ improves the quality of the seedlings, and this was statistically proven for the F48 family. Besides the ash contain nutrients for the seedlings, the ash fills large voids between aggregates of 10 to $4 \mathrm{~mm}$ results in pores with greater water retention capacity.

\section{Materials and methods}

\section{Plant materials}

The experiment was carried out in a greenhouse, located at the Federal Institute of Education, Science and Technology of Mato Grosso, in the municipality of Caceres, Brazil, located at coordinates 160 04 ' 14 ' ', latitude South, and 570 $40^{\prime} 44^{\prime \prime}$, longitude West. According to Köppen, the climate is tropical rainy, with average annual temperature ranging between 23 and $25^{\circ} \mathrm{C}$, and temperature oscillation in the year below $5^{\circ} \mathrm{C}$ and annual rainfall equal to $1,277 \mathrm{~mm}$ (Alvares et al., 2013).

The soil considered base for the substrates composition was collected from a pasture area, on the sides of the BR-070 (20 $\mathrm{km}$ from Cáceres-MT), whose soil was classified as eutrophic RedLatosol (RLe) (EMBRAPA, 2006). The soil was collected from the Bw horizon ( 40 to $150 \mathrm{~cm}$ ), aiming to reduce the occurrence of weed seeds and pathogens. The material obtained is termed gully soil.

\section{Experimental design}

The experiment was arranged in randomized block design, in a $2 \times 7 \times 2$ factorial scheme, with three replications and two pots per plot, which totaled 28 treatments. The first factor represented the two levels of soil structures with 4 to 10 $\mathrm{mm}$ aggregates and aggregates $<2 \mathrm{~mm}$. The second factor represented the seven levels of the doses of ashes from the sugarcane bagasse incorporated into the substrates. The third factor represented the two families of passion fruit, F29 and F48.

The soil was sieved in $10 \mathrm{~mm}, 4 \mathrm{~mm}$ and $2 \mathrm{~mm}$ meshes so as to obtain soil with two classes of aggregates. The first, with the aggregates retained between 4 and $10 \mathrm{~mm}$ and the second, with aggregates $<2 \mathrm{~mm}$. The pots were filled with the material obtained, in the amount corresponding to 2.4 $\mathrm{kg}$ of dry soil. The dry soil of each pot with its respective dose of ash was placed in a plastic bag with $20 \mathrm{~L}$ capacity, inflated with air and stirred to homogenize the substrate.

The ash from the sugarcane bagasse used in the experiment was obtained from the COOPERBE sugar cane plant (Lambari do Oeste- Mato grosso). The ash moisture was determined and the quantities of wet material were corrected in order to ensure the following dry ash doses: $0 ; 1.5 ; 3 ; 6 ; 12 ; 24 ; 48$ t ha- ${ }^{1}$. The quantities per pot were calculated considering the proportion of the volume of $2,000 \mathrm{~m}^{3}$ of soil per hectare. After the addition of the doses of each treatment, the pots were irrigated and maintained moist for 15 days until sowing was conducted. The fertilization of the pots was done by liquid route on the substrate surface, according to the recommendation for cultivation under greenhouse conditions, according to Novais et al. (1991).

The passion fruit seeds used in the experiment came from two families of the UNEMAT / UFV / UENF breeding program. Two equidistant seeds were sown in each pot. After three weeks of emergence, the seedlings were thinned with the conduction of only one plant per pot. The humidity corresponding to 60-70 of the total pore volume was established for humidity control. The pots were weighed every day for the estimation of water loss and its replacement through irrigation.

\section{Traits measured}

The variables studied were shoot fresh mass (MFPA), shoot dry mass (MSPA), soil density (DS) and water consumption per pot (CAV). The data of these variables were collected at 60 days after the implantation of the experiment. Plant height was measured weekly. 


\section{Statistical analysis}

The data were submitted to analysis of variance, using polynomials to describe the effect of the metric experimental factors. After adjusting the complete model with up to third-order terms, the non-significant terms were neglected and the resulting (reduced) model was used for performing parameter inference and value prediction. The $R$ DEVELOPMENT CORE TEAM software system (RDCT, 2009) was used in the analysis of all statistical data.

\section{Conclusion}

The soil structure $<2 \mathrm{~mm}$ combined with the ash doses resulted in a substrate that increased the shoot fresh mass and shoot dry mass.

The maximum ash dose of $48 \mathrm{tha}^{-1}$ had a negative effect on the final height of the seedlings of both families and increased the water consumption by the seedlings in the family F29.

\section{Acknowledgments}

The first author thanks the Coordenação de Aperfeiçoamento de Pessoal de Nível Superior (CAPES) and Conselho Nacional de Desenvolvimento Científico e Tecnológico (CNPq) for funding the research.

\section{References}

Alvares CA, Stape JL, Sentelhas PC, Gonçalves JLM, Sparovek G (2013) Köppen's climate classification map for Brazil. Meteorol Z. 22(6): 711-728.

Arruda MR, Pereira JCR, Moreira A, Teixeira WG (2007) Enraizamento de estacas herbáceas de guaranazeiro em diferentes substratos. Ciênc Agrotec. 31(1): 236241.

Bonfim-Silva EM, de Oliveira ES, Loiola-Bezerra MD, Castañon THM, Fenner W, Silva TJA (2017) Application of Wood Ash, Organomineral and Mineral Fertilizers to Increase the Growth of Arugula (Eruca sativa Miller) at Different Base Saturation on Oxisol. J Exp Agric Int. 17(3): 1-6.

Costa TR, Camargo R (2009) Produção de mudas de pinhão manso (Jatrophacurcas L.) em tubetes a partir de diferentes fontes de matéria orgânica. Rev Horiz Cient. 3(1):1-17.

Cunha AHN, Fernandes EP, Araújo FG, Malafaia G, Vieira JA (2015) Vermicompostagem de lodo de curtume associado a diferentes substratos. MSJ. 1(3): 31-39.

Duarte RF, Sampaio RA, Brandão-Júnior DS, Fernandes LA, Silva HP (2010) Crescimento inicial de Acácia em condicionador formado de fibra de coco e resíduo agregante. Rev Bras Eng Agríc Ambient. 14(11): 11761185.

Embrapa. Centro Nacional de Pesquisa de Solo (2006) Sistema brasileiro de classificação de solos. 2.rd edn. Rio de Janeiro, Rio de Janeiro. 306p.
Ferreira A, Gava MD, Lopes JC, Martins-Filho S (2002) Germinação de semente e desenvolvimento de plântulas de pimentão em substratos condicionados com hidroplan. Hort Bras. 20(1): 343.

Freitas AR, Lopes JC, Alexandre RS, Venancio LP, Zanotti RF (2015) Emergência e crescimento de mudas de maracujá doce em função de lodo de esgoto e luz. Com Sci. 6(2): 234-240.

Ibge (2018) Instituto Brasileiro de Geografia e Estatística. Produção agrícola municipal: culturas temporárias e permanentes. Rio de Janeiro. Disponível em: http://biblioteca.ibge.gov.br/index.php/bibliotecacatal ogo?view=detalhes\&id=766 (acesso em 28 março 2018).

Jesus ON, Soares TL, Oliveira EJ, Santos TCP, Farias DH, Bruckner CH, Novaes QS. (2014) Dissimilarity based on morphological characterization and evaluation of pollen viability and in vitro germination in Passiflora hybrids and backcrosses. Acta Hortic. 29: 401-408.

Kratz D, Wendling I (2013) Produção de mudas de Eucalyptus dunnii em substratos renováveis. Floresta. 43: 125-136.

Landis TD, Tinus RW, Mcdonald SE, Barnett JP (1990) Containers and growing media. In: The container tree nursery manual, v.2. USDA Forest Serv, Washington: 139.

Mendonça V, Araújo-Neto SE, Ramos JD, Pio R, Gontijo TCA (2003) Diferentes substratos e recipientes na formação de mudas de mamoeiro 'sunrise solo'. Rev Bras Frutic. 25: 127-130.

Novais RF, Neves JCL, Barros NF (1991) Ensaio em ambiente controlado. In: Oliveira AJ, Garrido WE, Araújo JD Lourenço S. (Coord.). Métodos de pesquisa em fertilidade do solo. Brasília: Embrapa-SEA.189-253.

Oliveira FT, Hafle OM, Mendonça V, Moreira JN, Mendonça LFM (2013) Fontes e proporções de materiais orgânicos na germinação de sementes e crescimento de plantas jovens de goiabeira. Rev Bras Frutic.35: 866-874.

Oza EF, Monaco PAVL, Santos MM, Rosado TL, Krause MR, Garcia WA (2018) Aproveitamento de escória de siderurgia em substratos alternativos para produção de mudas de pimenteira Dedo-de-moça. Rev Ceres 65: 104-109.

Piva R, Botelho RV, Ortolan C, Müller MML, Kawakami J (2013) Adubação em vinhedo orgânico da cv. Isabel utilizando cinzas vegetais e esterco bovino. Rev Bras Frutic. 35: 600-615.

Pio R, Araújo JPC, Bastos DC, Alves ASR, Entelmann FA, Sarpare-Filho JÁ, Mourão-Filho FAA (2005) Substrato no enraizamento de estacas herbáceas de figueira oriundas da desbrota. Ciênc Agrotec. 29: 604-609.

Rdct - R development core team (2009) R: a language and environment statistical computing. Vienna: $R$ Foundation for Statistical Computing.

Reis RVD, Viana AP, Oliveira EJD, Silva MGM (2012) Phenotypic and molecular selection of yellow passion fruit progenies in the second cycle of recurrent selection. Crop Breed Appl Biotechnol. 12:17-24. 
Sá FVS, Bertino AMP, Ferreira NM, Bertino AMP, Soares LS, Mesquita EF (2017) Formação de mudas de maracujazeiro amarelo com diferentes doses de esterco caprino e volumes do substrato. Magistra. 26(4): 482-492.

Santos CC, Motta IDS, Carneiro LF, Santos MCS, Padovan MP, Mariani A (2014) Produção agroecológica de mudas de maracujá em substratos a base de húmus de minhoca e casca de arroz carbonizada. Cader Agroecol. 9(4): 1-10.

Silva FHL, Viana AP, Ferreira RT, Freitas JCO, Santos JO, Rodrigues DL (2014) Measurement of genetic diversity in progenies of sour passion fruit by Ward-MLM methodology: a strategy for heterotic group formation. Ciênc Agrotec. 38:1234-1239.
Saarsalmi A, Kukkola M, Moilanen M, Arola M (2006) Long-term effects of ash and $\mathrm{N}$ fertilization on stand growth, tree nutrient status and soil chemistry in a Scots pine stand. For Ecol Manage. 235: 116-128.

Zietemann C, Roberto SR (2007) Produção de mudas de goiabeira (Psidiumguajava L.) em diferentes substratos. Rev Bras Frutic. 29: 137-142. 